\title{
OVERVIEW OF THE CURRENT CONDITION, IN PRODUCTION CONSUMPTION AND THE RESEARCH POTENTIAL OF THE RICE CROP IN THE REPUBLIC OF MACEDONIA
}

\author{
Danica Andreevska ${ }^{1}$, Mirjana Menkovska ${ }^{2}$, Dobre Andov ${ }^{1}$ \\ I"Ss Cyril and Methodius" University in Skopje, Agricultural Institute, Skopje, Republic of Maedonia. \\ 2"Ss. Cyril and Methodius" University in Skopje, Institute of Animal Science, \\ Bul. Ilinden 92-a, Skopje, Skopje, Republic of Macedonia, \\ danicaandreevska@yahoo.com
}

\begin{abstract}
The rice is a traditional cereal in the Republic of Macedonia, and through centuries it was mainly used as one of the essential food for its population. From the total area in the country $43,6 \%$ or $11210 \mathrm{~km}^{2}$ belong to the agricultural land from which $45,4 \%$ are cultivable. In this study we present the current condition in the production, processing, consumption and a part of the research work on rice in the Republic of Macedonia. We consider the main regions for rice growing, the meteorological data for rice vegetation, the sown rice areas and yields, taking also into consideration the areas preparing for rice sowing, application of fertilizers, their quality, the way and time of application, deseases and pests, the harvest way and processing of the crude rice (paddy), as well as the nutritive quality of rice kernel, cooking behavior in comparison with foregn rice varieties. We also consider here the scientific-reserch and applicative work on the rice production in the Republic of Macedonia which was mostly performed at the Rice Institute in Kochani, including breeding of new rice varieties, as well as production of quality seed material. As a result of the scientific-research work, domestic rice varieties were created such as: No-69, No -51, biser-2, kochanski, osogovka, nada-115, ranka, prima riska and montesa were also introduced and registrated. Foreign such as Italian rice varieties: monticheli, p-76/6, san andrea and drago, and new Bulgarian rice varieties: line 305, line-2, L.M-B.P., garant, zemja, mizia, kubrat, horizont, and dunav, were also introduced and registered and included in the Macedonian rice breeding programme. The main limiting factor in the rice production in the republic of Macedonia in future will be the water need for irrigation as well as the shortage of rice growing arable areas, as a consequence of the expansion of the urban environment. However, rice will also represent further a significant agricultural culture for the country, because it satisfies the total domestic rice needs, and significant quantities remain for export.
\end{abstract}

Kye words: rice; production; processing; consumption; varieties; seed; quality

\section{ПРЕГЛЕД НА ТЕКОВНАТА СОСТОЈБА ВО ПРОИЗВОДСТВОТО, КОНСУМАЦИЈАТА И ИСТРАЖУВАЧКИОТ ПОТЕНЦИЈАЛ НА ОРИЗОВАТА КУЛТУРА ВО РЕПУБЛИКА МАКЕДОНИЈА}

Оризот е традиционална житна култура во Република Македонија и низ векови таа била една од главните храни за нејзиното население. Од вкупната површина на земјата, 43,6\% или $11210 \mathrm{~km}^{2}$ им припаѓаат на земјоделското земјиште од кое што 45,4\% е обработливо. Во овој труд ја прикажуваме тековната состојба во производството, преработувачката, потрошувачката и дел од научно истражувачката работа на оризот во Република Македонија. Во предвид се земени главните региони за одгледување на ориз, метереолошките податоци за оризовата вегетација, посеаните оризови површини и приноси, како и подготовката на површините за сеење на оризот, примена на ѓубрива, нивниот квалитет, начинот и времето на примена, болестите и штетниците, начинот на жетвата и преработката на суровиот ориз-арпата, како и нутритивниот квалитет на оризовото зрно и готварските особини во споредба со странски сорти ориз. Овде исто така ја разгледуваме научно истражувачката и апликативната работа на производството на ориз во Република Македонија, која најмногу се изведува при Институтот за ориз во Кочани, вклучувајчи ја селекцијата на нови сорти ориз, како и производство на квалитетен семенски материјал. Како резултат на научно истражувачката работа, се создадени домашни сорти ориз No-69, No-51, бисер-2, кочански, осоговка, нада-115, ранка, прима риска и монтеса. Исто така воведени и регистрирани се италијански сорти ориз: монтичели, p-76/6, сан андреа и драго, и нови бугарски линии ориз: линија 305, линија-2, ЛМ-БП., гарант, земја, мизиа, кубрат, хоризонт и дунав, се вклучени во македонската селекциона програма. Главен 
ограничувачки фактор во производството на ориз во Република Македонија во иднина ќе биде недостигот од вода за наводнување и недостиг на обработлива површина за одгледување, како резултат на експанзијата на урбаните средини. Сепак, оризот и понатаму ќе претставува значајна земјоделска култура за земјата, бидејќи нејзиното производство ги задоволува домашните потреби, а значајни количества остануваат за извоз.

Клучни зборови: ориз; производство; преработка; потрошувачка; сорти; семе; квалитет

\section{INTRODUCTION}

Rice (Oryza sativa L.) is one of the oldest cereals. For the first time in Macedonia it was grown after Alexander Macedonian is returning from the campaign in India (in 356-323 B.C.) and again in the XIVth century with Turks, coming in all country regions with the exemption of that of the mountains.

Rice production in the Republic of Macedonia is mainly concentrated in the Eastern part along the course of the river Bregalnica in the regions of Kochani, Shtip, Vinica and Blatec, whereas in smaller areas is also represented in the regions of Veles and Probishtip.

In the past (the period of the 1970's/1992's ) the rice was also sown on the areas of 9500 ha. So, the greatest rice areas in Macedonia were planted in 1987 on 9675 ha with a total production of 49342 tons crude rice-paddy. With an annual production of about 45000 tons rice paddyies, that are 27000 tons white rice, Macedonia has satisfied $60 \%$ of the population need from the former state of Yugoslavia. But, the planted rice areas in recent years were rather variable, the same are significantly reduced, and the reasons were various factors (mostly lack of water coused by drought).

Rice is used as food, but it is also used as a raw material in the industry of starch, alcochol and alcocholic drinks. As essential macrobiotic food, rice is also introduced in our country lately. The yearly rice production per capita in Macedonia is about $7 \mathrm{~kg}$.

During the rice processing (whitenning) of crude rice into white rice, secondary products are also obtained, namely the hulls and bran which are used in industry and for preparation of various concentrates for nutrition of domestic animals.

The aim of this paper is to present the current condition in the production, consumption, and a part of the scientific-research work on rice in the Republic of Macedonia, as well as its perspectives.

\section{The Valey of Kochani, the principal rice production region}

The Valey of Kochani, the principal rice production region is situated in the northern-eastern part of Macedonia, around the course of the river Bregalnica, above the sea level of 291-330 $\mathrm{m}, 41^{\circ}$ $47^{\prime} 42^{\prime}$ ' eastern geographical width and $19^{\circ} 45^{\prime}$ 22 " eastern geographical length according to Greenwich.

High mountains on the border of the valley give it a special characteristic climate of this region. According to [1] Macedonia can be devided into eight climate-vegetation-soil-areas.

The valley of Kochani belongs to the second group of the so called continental-submediteranean areas, which are characterized by the most expressive translations of the continental and Mediteranean climate and with high temperature amplitudes.

The climate conditions of the region mostly depend on the geographical situation and of the relief.

The temperature is a significant factor which has an important influence on the rice biochemical processes. In addition to this, the optimal temperatures are required as well as the limited values under which they could not be carried out. The necessary average daily air temperature during the vegetation for a successful rice growing should be between $18-20{ }^{\circ} \mathrm{C}$.

Rice needs intensive sun light, while the diffuse light prolongs the period of maturation. In the rice producing regions should not there be strong wind which can enable threshing grains from the panicle, lodging, or pulling out the whole plants

According to Lazarevski (1993) the temperature sum during the rice vegetation in the Kochani region is in the frame from $2700^{\circ} \mathrm{C}$ to $4500^{\circ} \mathrm{C}$, which means that the essential growing conditions such as heat, water and light are covenient for rice growing.

Some metereological characteristics of the Kochani region during the rice vegetation are shown in Table 1. It should be said that the rains in our conditions have an indirect meaning concerning the rice growing, because they influence the quality of the accumulated water in the hydrosystem that supplies the area with water for irrigation during the whole vegetation period. 
Table 1

Meteorological data of the rice vegetation in Kochani region

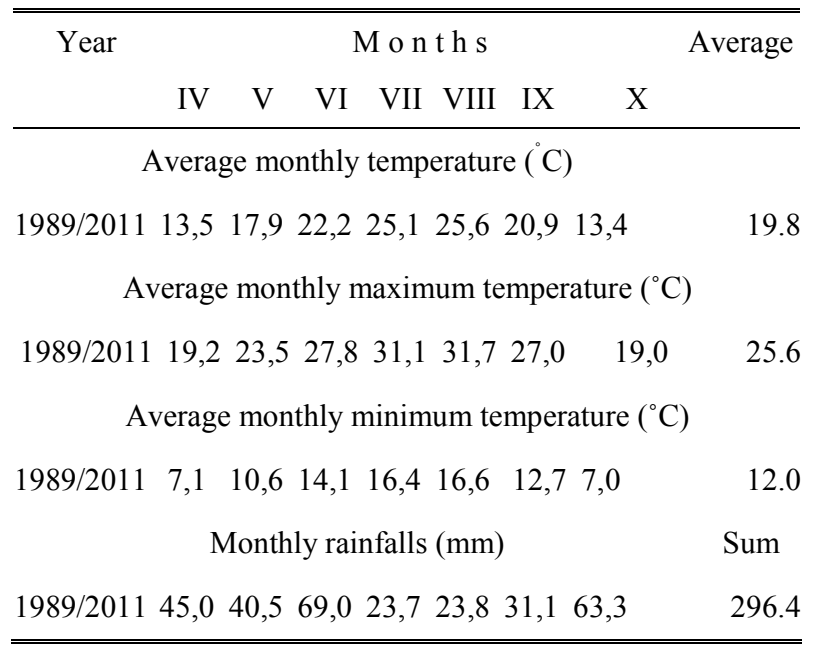

\section{Planted rice areas and yields}

In the last years the areas planted with rice in $\mathrm{R}$. of Macedonia, the average rice yield and the total rice production were very variable (Table 2). From the Table 2 it can be seen that the least planted areas were in 1994 (1200 ha), while the most in ones 1990 (8880 ha). The smallest yield per area unit was achieved in $1993(1830 \mathrm{~kg} / \mathrm{ha}$, as a result of the extreme dry year and the shortage of irrigation water, while the highest was in 2003 (6500 kg/ha).

The average yield of rice in the Republic of Macedonia is around $4099.7 \mathrm{~kg} / \mathrm{ha}$, which is very close to the average one of the countries in the European Community.

\section{Preparing the areas for rice planting}

The preparation of the areas for rice planting is performed in a mechanized way. On greater part of Macedonian rice areas, because of the inconvenient climate conditions in autumn, after the harvest, very rerely or autumn ploughing is not performed at all. The spring tilling reperents the principal part of the agricultural technology of the rice culture and consists of one plowing, and then disc ploughing is applied on the areas. Before the planting the land levelling, harrowing or the second disc ploughing are performed.

The optimal time for rice sowing begins in the second decade of April and lasts till the end of May. Very often manual seed broadcasting is applied into the watered soil.
Table 2 .

Sown areas, average yields and total rice production in Macedonia

\begin{tabular}{cccc}
\hline \hline Year & Areas & $\begin{array}{c}\text { Average yield } \\
\text { of paddy rice } \\
\text { (kg/ha) }\end{array}$ & $\begin{array}{c}\text { Total production } \\
\text { of paddy rice } \\
\text { (tons) }\end{array}$ \\
\hline 1989 & 6056 & 4536 & 27675 \\
1990 & 8880 & 3100 & 27386 \\
1991 & 8692 & 4314 & 37497 \\
1992 & 8465 & 5000 & 42000 \\
1993 & 3500 & 1830 & 6420 \\
1994 & 1200 & 5100 & 6120 \\
1995 & 1316 & 5200 & 6843 \\
1996 & 4800 & 5300 & 25440 \\
1997 & 5500 & 3600 & 19800 \\
1998 & 3905 & 4800 & 18744 \\
1999 & 3455 & 4870 & 16825 \\
2000 & 4510 & 4773 & 20430 \\
2001 & 1978 & 5204 & 8307 \\
2002 & 2450 & 4739 & 11025 \\
2003 & 3962 & 6500 & 25753 \\
2004 & 3870 & 5168 & 19350 \\
2005 & 2395 & 5270 & 12570 \\
2006 & 2524 & 5526 & 13944 \\
2007 & 2504 & 6132 & 15355 \\
2008 & 2586 & 6241 & 16140 \\
2009 & 3120 & 6368 & 19970 \\
2010 & 4125 & 6230 & 25700 \\
\hline \hline & 4500 & 5992 & 26964 \\
\hline & 4099,7 & $\mathbf{5 0 3 4 , 5}$ & $\mathbf{1 9 5 7 6 , 4}$ \\
\hline
\end{tabular}

According to the investigations of Andov et al. (2011) on the influence of method of sowing rice upon the yield and consumption of water for irrigation, the best results were achieved with the sowing variant by seeding machine on dry soil comparing with the manual seed broadcasting onto the watered soil. Irrigation is continuous with periodical drainage and drying the rice field according to the needs for treatment of herbicides, the algal appearance or of Apus cancriformis-the rice crab. Irrigation is by the method of flooding irrigation. It can be said that there is an average need of about 15000 to $18000 \mathrm{~m}^{3} /$ ha water. 


\section{Application of fertilizers, quality, time and the application way}

The investigations have shown that besides climate and soil conditions the applied agricultural technology (as it is the choice of variety, time of sowing, seed rate, crop rotation, precrop, and fertilisation) has also a great influence on the rice yield and quality. The correct and on time application of the agricultural technology in rice production reperesents a very important prerequisite for high yields and obtaining good quality.

Rice yields can be increased many times by fertilisation from $40-50 \%$, with good working of the soil $20-30 \%$, with application of quality seed material from $10-20 \%$ and with crop rotation of 9 $10 \%$.

The best yields are obtained if the areas intended for rice growing are fertilized after discation, before the rice planting with complex mineral fertilizers (NPK with different ratio of the active materials) or urea $[4,5,6]$. During the rice vegetation split application is performed according to the needs (with urea, uras or calcium ammonium nitrate - limestone KAN). During rice fertilization, the optimum nitrogen dose is from $120-140 \mathrm{~kg} / \mathrm{ha}$, and of phosphorus and potassium of $60-75 \mathrm{~kg} / \mathrm{ha}$. Nitrogen fertilizers are applied many times and mostly $2 / 3$ before planting, and one third during rice vegetation in the phase of tillering.

The protection from weeds, deseases and pests during rice vegetation, is performed by the rice producers according to the needs mostly with registrated protection means - pesticides. Because of the convenient climate conditions for rice growing the appearance of deseases is very rare, so the treatment with chemical means for that purpose is missed.

The most represented weeds in the rice fields in Macedonia are Echinochloa spp., as well as the species of the family Cyperaceae: Scirpus spp. and Ciperus spp. [7]. Very dangerous weed is the red rice which is very similar to the cultural (cultivated) rice, i.e is its variety, so its separation represents a dificulty [8].

An effective systematic fight against the weeds is the combination of preventive, mechanical, production and chemical methods. The chemical fight understands the application of herbicides which selectively control the sprouting and development of rice weeds when they are correctly applied. The efficiency of herbicides depends on the type and their combination and floral composition of rice weeds.
In the last years rice is rotating in crop rotation with other crops, and it should be pointed out that it has the primary meaning in the complex of the integral protection from weeds. At some particular conditions the scientific farming has appeared as prerequisite for better development or multiplication of rice weeds [9]. Actually the nivelation which is not well performed on the surfaces can be caused for their greater representaion. Introducing the integral measures for the fight against the weeds in the rice production, damages should be eliminated which are caused on the rice culture by them, greater yields will be achieved, rationalization of the production as well as its cheapness [10].

According to Karov (2001) a great number of rice diseases are represented in Macedonia caused by viruses, bacteria and molds. The viral and bacterial diseases are met less rarely, while mold deseases more often appeared.

The more frequent deseases are the following: Piricularia orizae Cavara, Helminthosporium oryzae Breda de Haan and Fusarium moniliforme Sheldon.

By investigating rice entomofauna in Macedonia the presence of the insects of the following 10 orders was determinated: Diptera, Homoptera, Himenoptera, Thysanoptera, Collembola, Coleoptera, Lepidoptera, Heteroptera, Orthoptera and Odonata [12].

The most numerous are the insects from the genus Diptera Brachycera with 189 species classified into 23 families. Among them the dominant are the species: Ephydra riparia Fall., Hidrellia griseola Fall., Notiphila stagnicola R.-D., Caenia fumosa Stenh., Dichaeta caudata Fall. (fam. Ephydridae), Chrysotus cilipes Meig. and Chrysotus suavis Lw. (fam. Dolichopodidae) [13]. In the fauna of Diptera Brachicera the harmful species are more reperesented in the quantitative (26.34 $\%)$, than in the qualitative composition (1.06\%).

\section{Time, harvest way and processing of paddy}

Rice harvest in the Republic of Macedonia is performed by mechanised way (with combine) in October.

After the harvest the crude rice (paddy) is stored in appropriate storehouses where the following operations are performed: giving shelter, cleaning, drying, storage, processing and distribution, and be preserved in sanitary, chemical and technologycal proper conditions. The duaration period and the way of storage of paddy rice depend on a few factors. 
Because the paddy kernel is covered with glume-shulls it is not directly suitable for nutrition. For the purpose of their removal, after the harvest processing there are factories (mills) completely equipped with special machines for each operation.

During rice processing the following operations are conducted: cleaning, drying, paddy dehulling, separation of the dehulled from unhulled rice, whitening, separation of whole kernels from brokens, cleaning stone from white rice, colour grading, packing and storage.

In relation to the degree of finishing work various rice kinds are obtained: husked rice (cargo or brown rice), white rice, glazed rice and vitaminised rice.

The composition, i.e. reperesentation of particular nutritive components in the rice kernel, are the basic characteristics of its kind, although there are some exceptions in relation to the variety, soil and climate conditons, and the intensity level of the change of particular measures of scientific farming (fertilization, usage of some chemicals or physical biostimulators) and so on.
The results of investigations of protein content in the husked kernel of paddy and brown rice of 61 varieties of domestic and foreign origin (Italy, USA, Russia, China, Corea, France and Bulgaria) have shown that the proteins varied a lot and their content in the investigated varieties is from $6.72-10.12 \%$ in paddy and from $6.31-10.29 \%$ in cargo rice. Among domestic varieties with the highest protein content was the variety No. 51 (paddy $-9.52 \%$, cargo $-9.88 \%$ ), while among the foreign varieties: the Italien - Rodio (paddy 9.52\%, cargo - 9.88\%); the American - Lemont (paddy $-10.12 \%$, cargo $-9.88 \%$ ); the Chinese $-S i$ jon $N^{\circ} 6$ (paddy $-10.00 \%$, cargo $-10.29 \%$ ) and the Russian - Uzros 275 (paddy - 9.10\%, cargo $8.98 \%$ ) [14]. The varieties with the highest protein content are used as parents in the breeding programmes of the breeding new high protein rice varieties.

The basic rice quality is based on its chemical composition, i.e.of the content of: water, nitrogenless extractable materials (carbocitrates), crude proteins, fats, fiber and ash (Table 3) and it depends on the degree of processing [15].

Table 3

Rice kernel chemical composition (Vasilevski, 1997) (\%)

\begin{tabular}{lcccccc}
\hline \hline Type of rice & Water & Carbohydrates & Crude proteins & Fats & Cellulose Fiber & Ash \\
\hline Paddy rice & 13.50 & 66.00 & 6.80 & 1.60 & 7.41 & 4.07 \\
Brown or Cargo rice & 10.40 & 77.20 & 7.90 & 2.90 & 3.50 & 1.50 \\
White or Milled rice & 11.40 & 79.90 & 7.10 & 0.70 & 1.00 & 0.60 \\
Parboiled & 10.20 & 81.70 & 6.80 & 0.70 & 1.80 & 0.80 \\
Precooked or instant & 8.10 & 83.60 & 7.70 & 0.30 & 1.60 & 0.30 \\
\hline \hline
\end{tabular}

However there are significant differences in the content of all compositional components between the brown (cargo) rice and white rice, products which are obtained by the classical method of husking rice, as well as parboiled and precooked rice, products which are obtained by new technological methods.

From 1980 the production in the R. of Macedonia has began from the so called „Parboiled“" naturally vitaminised rice, a product which was known earlier in the European countries. By this technology the crude rice-paddy before husking it underwent to a treatment with steam or hot water. Through the process of vitaminisation small pro- tein and starch quantitities get lost, while in water dissolved vitamins and mineral materials with diffusion are transferred from the coat into the kernel. By this treatment the yield of dressing percentage was enabled and the content of vitamins and mineral materials, too (Table 4). Because of its quality proprerties the naturally vitaminilised rice is included in the palette of the products "Food 5", which have a higher nutritional value.

In the latest time a particular interest of investigation is devoted to the secondary rice products-the hulls and bran which are obtained in the production, i.e. during the processing of the crude rice-paddy into white rice $[16,17]$. Their composi- 
tion, which is rich in silicium content in the hulls and fat in the bran, contributed them to be significant raw materials in the fat industry.

\section{Table 4}

Vitamin and mineral content in rice kernel ( $\mathrm{Va}$ silevski, 1997) ( $\mathrm{mg} / \mathrm{kg})$

\begin{tabular}{cccc}
\hline \hline $\begin{array}{c}\text { Vitamins and } \\
\text { minerals }\end{array}$ & Paddy rice & White or milled rice & Parboiled \\
\hline B1 & 4.3 & 0.5 & 1.9 \\
B2 & 0.4 & 0.1 & 0.2 \\
PP & 73 & 6.5 & 59 \\
B5 & 12 & 3.7 & 11 \\
B6 & 5.7 & 1.3 & 5.6 \\
Phosphorus & 3200 & 830 & 1210 \\
Potassium & 2300 & 650 & 1230 \\
\hline \hline
\end{tabular}

The rice bran is a good source of nutritional, stable and sound oil, while, hulls are good absorbent for oil bleeching. The rice bran and hulls are used together as agents for purification of the waste waters [18]. The presence of the enzyme lipase in the rice bran causes fast rancidity.

The main characteristics of rice hulls is the high silicium content. Compared to the bran from other cereals, the rice bran is rich in lipids, proteins, fibre, minerals, vitamins of the $\mathrm{B}$ group, phytine, phospholipids, and waxes. The bran can also contain enzymes, microorganisms, insects, and other possible harmful contaminants.

\section{SCIENTIFIC-RESEARCH WORK ON RICE IN THE REPUBLIC OF MACEDONIA}

The scientific-reserch and applicable work on the rice production in the Republic of Macedonia have mostly been performed at the Rice Institute in Kochani, which became a part of the Agricultural Institute of the Ss Cyril and Methodius University (UKIM) in Skopje in 1999 till now-a-days.

The main research subjects were the following:

- Breeding and introduction of new rice varieties;

- Production of quality seed material;

- Introduction and modernization of the mechanization in the rice production;
- Investigation and application of pesticides (integral protection from the weeds, diseases and pests);

- Correct application of the fertilizers (quality, time, and the way of their application), and according to the results obtained from the agrochemical analyses for the investigation of the soil fertility and the needs of the rice plants;

- Investigation of the quality properties of paddy and white rice;

- Rationalization of rice production and its cheapness;

- Production of healthy food.

\section{Breeding of new rice varieties and introduction and registration of foreign rice varieties}

As a result of the scientific-research work domestic rice varieties were bred: No-69, No-51, biser-2, kochanski, osogovka, nada-115, ranka, prima riska and montesa [19, 20,21].

The Italian varieties: monticheli, p-76/6, san andrea and drago were introduced and registered which are characterized with properties needed at the market.

Information about the agronomical and technological quality of domestic and introduced rice varieties can be found in the literatutre.

The Rice Institute possesses and preserves a collection of 220 rice varieties and a great number of new genotypes from all over the world.

Expanding the genetic basis of the existing productional assortment and evaluable breeding material is a continuous process. In 2003 new 10 Italian rice varieties were introduced. Varieties kastelmochi, cistela, diana, italmochi, prometeo, ringo and selenio belong to the japonica rice type, while the varieties andola, dedalo and pegaso belong to the indica type [22].

The collaboration and exchange of the genetic materials with the Institute of Plant and Genetic Resources from Sadovo, Bulgaria, in 2005 enabled the nine new Bulgarian rice varieties (line 305, line-2, L.M-B.P., garant, zemja, mizia, kubrat, horizont, and dunav) to be included in the Macedonian rice breeding programme as well as in the comparing studies with rice standards [23]. The following Italian varieties were introduced in 2009 and 2010: bianka, galileo, brio, ellebi, and opale, which were also included in the investigation programmes. 
The Rice Institute contributes to the development of rice production technology and establishes a collaboration with farmers-the rice producers through the application of new growing technologies developed on the basis of its own scientific-research work.

The technological quality properties of some milled Macedonian rice varieties as well as of some introductions were also investigated according to the world standards [24]. The kernel type was characterized by the lengh/weight ratio. From the obained results presented in Tables 5 and 6 can be seen that Macedonian rices are characterized as short and medium long kernels. According to the physical properties, farinaceousnees, and cooking behaviour Macedonian rices are similar to the Italian and Spanish rices, as was shown by the values of amylase, alkaline spreading, and the temperature type of gelatinization.

Among the analysed rice varieties, the varieties $R-76 / 6$ and monticheli are Italian varieties, while the variety iskra is a Bulgarian variety.

Table 5

Some characteristics of milled Macedonian rice varieties (Menkovska at al,1988)

\begin{tabular}{|c|c|c|c|c|c|c|c|}
\hline Variety & Type $^{1}$ & $\begin{array}{l}\text { Length } \\
(\mathrm{mm})\end{array}$ & $\begin{array}{l}\text { Width } \\
(\mathrm{mm})\end{array}$ & $\begin{array}{l}\text { Tick } \\
(\mathrm{mm})\end{array}$ & Length/Width Ratio & $\begin{array}{l}\text { Kernel weight } \\
\text { (g) }\end{array}$ & Endosperm structure ${ }^{2}$ \\
\hline $15-38$ & $\mathrm{~S}$ & 6.26 & 2.91 & 2.01 & 2.16 & 28.5 & 93 \\
\hline Kochanski & S & 6.35 & 3.01 & 1.99 & 2.11 & 29.5 & 93 \\
\hline Biser & $\mathrm{K}$ & 5.92 & 3.36 & 2.01 & 1.76 & 33.6 & 99 \\
\hline Iskra & $\mathrm{K}$ & 5.41 & 3.07 & 2.07 & 1.76 & 25.3 & 95 \\
\hline$R-76 / 6$ & $\mathrm{~K}$ & 6.02 & 3.02 & 2.16 & 1.99 & 30.5 & 96 \\
\hline Monticheli & $\mathrm{K}$ & 5.34 & 3.00 & 2.01 & 1.78 & 23.7 & 98 \\
\hline Osogovka & $\mathrm{K}$ & 5.35 & 3.44 & 2.17 & 1.55 & 31.5 & 98 \\
\hline
\end{tabular}

${ }^{1} \mathrm{~K}=$ short kernel; $\mathrm{S}=$ middle long kernel; ${ }^{2}$ Percentage of endosperm structure indicates the degree of farinaceousness

Table 6

Some characteristics of milled Macedonian rice varieties (Menkovska at al,1988)

\begin{tabular}{lccccc}
\hline \hline \multirow{2}{*}{ Variety } & Amylazen (\%) & \multicolumn{3}{c}{ Value of alcaline spreading $^{1}$} & $\begin{array}{c}\text { Temperature type }^{2} \\
\text { of gelatinization }\end{array}$ \\
\hline 15-38 & 21.7 & Min. & Maks. & Average value & Low \\
Kochanski & 19.5 & 7 & 7 & 7.0 & Low \\
Biser & 20.0 & 6 & 7 & 6.8 & Low \\
Iskra & 20.2 & 7 & 7 & 6.3 & Low \\
R-76/6 & 20.1 & 7 & 7 & 7.0 & Low \\
Monticheli & 18.9 & 6 & 7 & 7.0 & Low \\
Osogovka & 18.6 & 6 & 7 & 6.9 & Low \\
\hline \hline
\end{tabular}

${ }^{1}$ In $1,7 \% \mathrm{KOH}$ solution; ${ }^{2}$ Temperature type of gelatinization based on the values of alkaline spreading

\section{Production of quality seed material}

The Agricultural Institute at UKIM in Skopje, is preserving the registered rice varieties in Macedonia and it is producing the basic seed material. The production of the lower seed categories is or- ganized in collaboration with the farmers. The rice seed production according to the varieties and years is presented in Table 7. From this Table it can be ssen that the seed production is decreasing from year to year, because numerous rice areas are 
decreasing, as well as decreasing of the financial power of the rice producers. The most represented rice varieties in the last years in the massive pro- duction are the introduced Italian varieties:san andrea and $R-76 / 6$, and among domestic varieties prima riska.

Table 7

Production of rice seed per varieties and per years (t)

\begin{tabular}{ccccccccc}
\hline \hline Year & Monticheli & $R-76 / 6$ & Osogovka & Kochanski & Biser-2 & San Andrea & Prima riska & Total \\
\hline 1989 & 16.8 & 27.9 & 1.7 & 0.7 & - & - & - & 47.1 \\
1990 & 63.3 & 40.1 & 2.4 & 1.6 & 0.5 & - & - & 107.9 \\
1991 & 60.4 & 32.7 & 1.8 & 1.2 & 0.5 & - & - & 96.6 \\
1992 & 298.4 & 77.1 & - & - & - & - & - & 375.5 \\
1993 & 44.2 & 29.5 & - & - & 0.8 & - & - & 74.5 \\
1994 & 86.0 & 24.2 & - & - & 1.9 & - & - & 112.1 \\
1995 & 56.3 & 74.4 & - & - & - & - & - & 130.7 \\
1996 & 93.9 & 67.7 & - & - & - & - & - & 161.6 \\
1997 & 61.0 & 58.9 & - & - & - & - & - & 119.9 \\
1998 & 105.0 & 18.7 & - & - & - & 5.2 & - & 128.9 \\
1999 & 82.8 & 9.5 & - & - & - & 1.4 & - & 93.7 \\
2000 & 38.9 & 12.5 & - & - & - & 12.9 & - & 64.3 \\
2001 & 20.4 & 5.9 & - & - & - & 7.6 & - & 33.9 \\
2002 & - & 13.4 & - & - & - & 7.9 & - & 21.3 \\
2003 & - & - & - & - & - & 3.0 & - & 3.0 \\
2004 & 5.0 & - & - & - & - & 10.0 & - & 15.0 \\
2005 & - & 1.0 & - & - & - & 2.1 & 2.1 & 5.2 \\
2006 & 3.8 & 4.4 & - & - & - & 14.8 & 3.0 & 26.0 \\
2007 & 8.7 & 12.6 & - & - & - & 24.3 & 0.8 & 46.4 \\
2008 & 9.7 & 7.5 & - & - & - & 11.0 & 1.0 & 29.2 \\
2009 & 4.0 & 2.0 & - & - & - & 20.0 & 1.0 & 27.0 \\
2010 & 4,0 & 2,0 & - & - & - & 20,0 & 1,0 & 27.0 \\
\hline \hline
\end{tabular}

\section{Proposal compilation}

At the Agricultural Institute a great number of scientific-research projects are compiled in connection with rice, proposals on the soils in order a detailed hydrosytems net in the Republic of Macedonia to be projected and built (in the regions of Skopje, Radovish, Gostivar Plane and Probishtip).

The work on the hydrosystem "Bregalnica" (in the regions of Kochani, Shtip and Ovche Pole) is of particular meaning, as well as proposals for production purposes of the soils which belong to the Agricultural combines, cooperative and individual farmers in the Eastern part of the Republic of Macedonia.

The Agricultural Institute was awarded with the Golden medallion, i.e. for the Patent of the Year-2000 at Brucelles - Eureka-2000 for the Elaborate on the protection of the designation of the origin of the "Rice from Kochani" at the Ministry for Economy - the Bureau for Protection of the Industrial Property in Skopje, for the first recognized designation of the origin of the rice from Kochani. 


\section{CONCLUSION}

From the above presented review of the current conditions in the production, consumption and a part of the results of the scientific-research work on the rice in the Republic of Macedonia, the following conclusions can be drawn:

- The rice production in the Republic of Macedionia varies greatly concerning the planted areas and the yield, but however, rice will represent further a significant agricultural culture for our country, because it satisfies the total domestic rice needs, and significant quantities remain for export.

- The obtained results from the scientificresearch work on which rice production and processing are based, as well as the covenient soil-climate rice growing conditions are a solid base for its further growing and developing.

- Improvement of the production technology, the processing and marketing will also represent the main subject and goal of the rice research in future.

- The main limiting factor in the rice production in the Republic of Macedonia in future will be water need for irrigation as well as the shortage of rice growing arable areas, as a consequence of the urban environment expansion.

\section{REFERENCES}

[1] Filipovski, Gj., Rizovski, R., Ristevski, P. (1996): Characteristics of climate-vegetation-soil-areas in R. Macedonia. MANU, Skopje.

[2] Lazarevski, A. (1993): Climate in Macedonia. Culture, Skopje.

[3] Andov Dobre, Andreevska Danica, Simeonovska Emilija, Jankuloski Ljupcho (2011): Influence of method of sowing rice (Oryza sativa L.) upon the yield and consumption of water for irrigation. Yearbook of the Faculty of Agricultural sciences and food, Skopje, vol. 56, 7-15.

[4] Bojadžieva N. (1981): The Use of Comlex Fertilizers on the Increase of Yield of Rice, "Agrohemija", No 1-2, Beograd.

[5] Gjorgjiev M., Andreevska Danica (1990): Effect of varied $\mathrm{N}$-nutrition on the yield, chlorophyll content in the leaves and total nitrogen, proteins, their fractions, phosphorus and potassium content in the grain of rice. God. zb., Biol., Skopje, tome 41-42, 351-369.

[6] Final Report on the Research Project. (1998): Influence of method and time of usage of nitrogen on yield and quality of the grain of two rice varieties and contents of available manganese and magnesium in rice soils. Kochani.
[7] Serafimov, I. (1973): The Weeds in the Rice Fields in Kochani Region and Results from the Chemical Protection Against Them. Macedonian Academy of Sciences and Arts. Simposium of Weeds, Skopje, 111-117, MANU.

[8] Gjorgjieva, V. (1997): Some characteristics of hybrids obtained by hybridization of cultural white varieties and red-grain genotypes of rice. Master thesis, Skopje.

[9] Andov, D. (1997): Morphological-biological and chemical-technological properties of rice varieties grown as first and second crop. Master thesis, Skopje.

[10] Tomeva Elizabeta (2000): Integrated protection against weeds in rice production and opportunities for the production of healthy food. Brochure p.71, Kochani.

[11] Karov, I. (2001): Rice diseases. Kochani: "Evropa 92", 264, Kochani.

[12] Tomeva Elizabeta (1998): Composition of the Rice Entomofauna in Macedonia. Proceedings of Papers XXIII Meeting "Faculty With Farmers" '98, Skopje, vol. 6, 7385, Skopje.

[13] Tomeva Elizabeta (2004): Diptera Brachycera Fauna of Rice in The Republic of Macedonia. Yearbook of the Institute of Agriculture -Skopje, vol.XXII/XXIII: 141-154, Skopje.

[14] Andreevska, Danica, Ilieva, Verica (1999): Grain protein content of different rice varieties. Book of papers of the 16 th Congress of chemists and technologists of Macedonia (with international participation), Skopje, vol. 1, p. 267-270.

[15] Vasilevski, G., Nikolov, P. (1997): Rice Production and Processing. Tribina Makedonska, p. 160; $21 \mathrm{~cm}$ (Biblioteka Agronauka), Skopje.

[16] Deckere, E. A. M., Korver, O. (1996): Minor constituents of rice bran oil as functional foods. Nutrition Reviews, 54, S120S126.

[17] Bocevska, Mirjana (2006): Rice: Bran and hull in oil industry . Journal of edible oil industry uljarstvo, 37, 3-4, $15-27$.

[18] Bocevska, M., Aldabas, I., Ilieva, V., Andreevska, D. (2004): Use of rice hulls and bran for removal of metal ions from waste water. XVIII Congress of chemists and Tehnologists of Macedonija, Extended abstracts, CDROM, COBISS, MK-ID 58455050, Ohrid.

[19] Final Report on the Research Project (1994): Breeding of rice. Kochani.

[20] Final Report on the Research Project (2002): Creation of new genotypes of rice with hybridization between geographically remote parental forms. Kochani.

[21] Final Report on the Research Project (2006): Creation of new rice genotypes with classical and opportunity for application of modern methods.

[22] Ilieva Verica, Andreevska Danica, Andov Dobre, Zaševa Tanja, Markova Natalija (2007): Comparative examination of some productive - technologikal characteristics of introduced and standard varieties of Rice (Oryza sativa L.).Yearbook of The Faculty of Agriculture Goce Delcev University, Štip, Vol. VII, 35-47.

[23] Ilieva Verica, Andreevska Danica, Natalija Markova (2008): Growth and productive-technological characteris- 
tics of introduced rice genotypes (Oryza sativa L.) within agroecological conditions of the Kocani region. Yearbook of Faculty of Agriculture, Štip, vol. 8, 27-36
[24] Menkovska, M., Pomeranz, Y., Webb, B. D. (1988): Characterization of Yugoslav Rice Varieties, Zyto Hleb, vol. 15, 3, 87-91. 